\title{
Ageing behaviour of polyacrylamide-based excavation fluids
}

1 Carlos Lam DPhil, CEng, MICE, MHKIE Formerly Lecturer in Geotechnical Engineering, School of Mechanical, Aerospace and Civil Engineering, The University of Manchester, Manchester, UK
2 Stephan A. Jefferis PhD, CEng, CEnv, CGeol, FICE, FGS Director, Environmental Geotechnics Ltd., Adderbury, Banbury, UK; Visiting Professor, Department of Engineering Science, University of Oxford, Oxford, UK
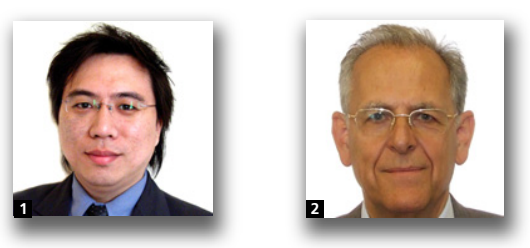

Solutions of synthetic polymers based on the chemistry of partially hydrolysed polyacrylamides (PHPAs) are increasingly being used as a replacement for the more conventional bentonite slurries in the construction of bored piles and diaphragm walls. On a construction site, these fluids may be in use for weeks to months and therefore their ageing behaviour is important. However, rather little has been published on the subject and the literature that is available is contradictory. To develop the understanding of ageing behaviour, a series of tests were undertaken on clean solutions of a commercial PHPA designed for civil engineering works. The tests showed that the PHPA fluids showed a gradual reduction in viscosity over the first days after mixing and that the rate of reduction was slightly dependent on the quality of the mix water. These findings are contrary to the rapid initial reduction in viscosity reported in some studies. An extended ageing test showed that the reduction in viscosity had effectively ceased at about $60 \mathrm{~d}$ from mixing with a significant proportion of the initial viscosity retained. These test results will allow foundation contractors to be more confident about the use of PHPA support fluids over extended times.

\section{Introduction}

Since the early 1950s, excavations for underground structural elements such as bored piles (drilled shafts) and diaphragm walls have been commonly carried out under the support of bentonite slurry. The bentonite slurry used is a diluted suspension of sodium montmorillonite clay. The physical properties of the slurry can have a significant impact on the quality and performance of the completed structural element. A wealth of knowledge on the use of bentonite slurry is now available in the construction industry (e.g. FPS, 2006; Suckling et al. 2011).

In the early 1990s, solutions of high-molecular-weight partially hydrolysed polyacrylamides (PHPAs) became available to construction contractors and are now increasingly used as alternative support fluids for geotechnical construction in many countries (Lam and Jefferis, 2014a, 2015a). The PHPAs used in construction are synthetic materials manufactured to have a high molecular weight, typically between 15 and 25 million $\mathrm{g} / \mathrm{mol}$ and an anionic charge on the polymer molecules. When dissolved in water they form solutions with non-Newtonian flow characteristics. Compared with their bentonite counterparts, PHPAs offer many advantages including improved concrete-soil interface resistance (Lam et al., 2014a), smaller site footprint (Lam et al., 2014b; Lennon et al., 2006) and reduced environmental impact (Schünmann, 2004). A general introduction to the use of polymer support fluids for geotechnical construction can be found in Jefferis and Lam (2013).

A key factor in excavation support is the control of fluid loss from the hole. With bentonite slurries this is achieved by the formation of a filter cake on the exposed soil surface (Jefferis and Lam, 2012). Polymer support fluids behave very differently - they continue to seep into the ground at a rate which is controlled by their rheological properties and, in particular, their high apparent viscosity at low-to-medium shear rates. As 
noted by Lam and Jefferis (2014a), a polymer product known as 'Telmarch' was developed and used in Japan in the 1970s, but its use gradually declined due to problems in maintaining its properties during excavation of deep trenches over extended periods of time. The authors believe that Telmarch was a biodegradable natural polymer, possibly a guar gum or a xanthan gum. As synthetic polymers are potentially more resistant to microbial attack, their solutions should be more stable with time. This research aims to confirm the greater stability of synthetic PHPAs and hence their suitability for civil engineering works where the excavation fluid may be in a cycle of use, storage and reuse over timescales of weeks to months.

Ageing behaviour is of considerable practical importance to foundation contractors but there is little information currently available in the civil engineering literature. Some laboratory studies on PHPA ageing have been reported by polymer scientists; Table 1 summarises the results from the available studies. It can be seen that a wide variety of ageing behaviours has been reported. These range from an initial rapid decline in viscosity (Kulicke and Kniewske, 1981; Shyluk and Stow, 1969), through negligible change (Mächtle, 1982), to a significant rise in viscosity (Likos et al., 2004). Other behaviours such as a slow decline (Henderson and Wheatley, 1987) and an inverted V-shape viscosity profile (Gardner et al., 1978) also have been reported. As the sample preparation procedures, test methods and the materials used for these studies vary considerably, it is not possible to draw any consistent conclusions that can be applied in civil engineering.

To develop a better understanding of the ageing of PHPA fluids and the viability of their use over extended times, a laboratory study has been conducted using a high-molecular-weight PHPA which is marketed for geotechnical excavation works. To ensure relevance of the results to civil engineering, the test fluids were prepared according to common site procedures. The experimental details and the test programme are set out below.

\section{Experimental details}

\subsection{Materials used and fluid preparation}

A commercial PHPA known as 'Shore Pac' was used to prepare the test fluids. This polymer is supplied in dry granular form by CETCO Drilling Products. The molecular weight and the degree of hydrolysis have been determined as $20 \times$ $10^{6} \mathrm{~g} / \mathrm{mol}$ and $39 \%$, respectively. These properties are typical of PHPAs used for civil engineering works, so the test results from this study should be indicative of the ageing behaviour of other civil engineering PHPAs.

To assess the effect of mix water quality, both deionised and Oxford tap waters were used to prepare the polymer fluids. Oxford tap water, which has a total hardness of around
$260 \mathrm{mg} / \mathrm{l}$ calcium carbonate $\left(\mathrm{CaCO}_{3}\right)$, was chosen as an example of hard mains water. Such hard waters are not unusual in many parts of the world. In line with the manufacturer's recommended practice, before use the hard water was treated with sodium carbonate (soda ash, $\mathrm{Na}_{2} \mathrm{CO}_{3}$ ) to raise the $\mathrm{pH}$ to 10 . An addition rate of $0.9 \mathrm{~kg} / \mathrm{m}^{3}$ was found to be sufficient to raise the $\mathrm{pH}$ to 10 , a level sufficient to precipitate the calcium hardness as calcium carbonate. Magnesium hardness that was present as about $10 \%$ of the total harness is not precipitated by this treatment.

After the mix water treatment, dry polymer granules were added to achieve a concentration of $0.8 \mathrm{~kg} / \mathrm{m}^{3}$. To avoid shear degradation of the polymer molecules, a low-shear laboratory mixer (Lightnin brand; model L1U08F) rotating at a speed of $500 \mathrm{r} / \mathrm{min}(\mathrm{rpm})$ was used to disperse the polymer granules during powder addition. This speed was chosen from preliminary trials, which showed that the mixer when operated at rotational speeds in the range from 400 to $600 \mathrm{r} / \mathrm{min}$ could provide sufficient agitation to disperse the granules in up to 2 litres of mix water. However, in order to avoid shear degradation due to prolonged higher-speed mixing (Lam et al., 2010; Nakano and Minoura, 1978), after wetting out the polymer granules the speed was reduced to $200 \mathrm{r} / \mathrm{min}$ and this was maintained for $45 \mathrm{~min}$ to promote full solution of the polymer. By $45 \mathrm{~min}$, a clear viscous solution had formed and was ready for the ageing tests.

\subsection{Instruments and test programme}

A Brookfield viscometer was used as the primary test instrument to investigate the ageing behaviour of the fluids. Figure 1 shows a photograph of the viscometer. The operating principle of the Brookfield viscometer is the measurement of the shear stress acting on a rotating cylinder (spindle) immersed in the test fluid. The same viscometer was used by Lam et al. (2014c) to study polymer sorption onto soils. The standard spindle LV-1 was used for all the ageing tests. According to the supplier, this spindle is suitable for measurements over a viscosity range from 15 to $20000 \mathrm{mPa}$ s (millipascal-second). The viscometer model used by the authors (DV-II+) has an analogue output, which allows the viscometer readings to be continuously logged. For these long-term studies, as evaporation of the test fluid is an issue, the specimen was sealed by wrapping the beaker of the test fluid and the viscometer head assembly with plastic film with a final layer of aluminium foil to exclude light and thus the potential for photodegradation, which according to some may lead to loss of physical properties of the polymer due to cleavage of the polymer backbone (bond scission), cross-linking and the formation of lower-molecularweight products (Caulfield et al., 2002). The experimental setup allowed measurements to be made continuously over an extended period of time without any significant loss of water by evaporation. The test was set up in a controlled temperature room maintained at $23^{\circ} \mathrm{C}$. 


\begin{tabular}{|c|c|c|c|c|c|c|}
\hline \multirow{2}{*}{$\begin{array}{l}\text { Reference } \\
\text { Shyluk and Stow } \\
\text { (1969) }\end{array}$} & \multirow{2}{*}{$\begin{array}{l}\text { Source materials } \\
\text { Polyacrylamide (PHPA) of } \\
\text { high intrinsic viscosity } \\
\text { (molecular weight) }\end{array}$} & \multicolumn{2}{|c|}{ Fluid preparation method } & \multirow{2}{*}{$\begin{array}{l}\text { Viscosity test } \\
\text { instrument } \\
\text { Capillary viscometer }\end{array}$} & \multicolumn{2}{|c|}{ Findings } \\
\hline & & $\mathbf{\square}$ & $\begin{array}{l}\text { Diluted polymer solutions prepared } \\
\text { immediately after polymerisation at } 35^{\circ} \mathrm{C} \\
\text { Specimens were tumbled at room } \\
\text { temperature during the ageing period }\end{array}$ & & - & $\begin{array}{l}\text { Viscosity decreased rapidly for the first } 10 \mathrm{~d} \text { followed by } \\
\text { a slow reduction stage } \\
\text { Weissenberg effect (fluid climbing up stirrer rod) also } \\
\text { weakened during the initial rapid ageing stage }\end{array}$ \\
\hline $\begin{array}{l}\text { Gardner et al. } \\
\text { (1978) }\end{array}$ & $\begin{array}{l}\text { Four high-molecular-weight } \\
\text { polyacrylamides }\end{array}$ & a & $\begin{array}{l}\text { Details not given } \\
\text { Fluid specimens were stored in flasks } \\
\text { at } 30^{\circ} \mathrm{C} \text { for } 24 \mathrm{~h} \text { before testing }\end{array}$ & $\begin{array}{l}\text { Not given; possibly a } \\
\text { capillary viscometer }\end{array}$ & - & $\begin{array}{l}\text { Viscosity increased to a maximum value between } 5 \text { and } \\
24 \mathrm{~h} \text { after mixing then decreased to a minimum value } \\
\text { after } 140 \mathrm{~h} \\
\text { Three of the four specimens then showed an increase } \\
\text { after } 240 \mathrm{~h}\end{array}$ \\
\hline $\begin{array}{l}\text { Kulicke and } \\
\text { Kniewske (1981) }\end{array}$ & $\begin{array}{l}\text { Three polyacrylamides with } \\
\text { degrees of hydrolysis of } \\
8,18 \text { and } 42 \%\end{array}$ & $\begin{array}{l}\mathbf{\square} \\
\mathbf{\square}\end{array}$ & $\begin{array}{l}\text { Distilled water and sodium chloride } \\
(\mathrm{NaCl}) \text { solution were used for mixing } \\
\text { After polymer addition, shaking for } 24 \mathrm{~h} \\
\text { until visual homogeneity } \\
\text { Stock solutions filtered and diluted }\end{array}$ & Rotational viscometer & च & $\begin{array}{l}\text { If prepared with distilled water, the higher the degree } \\
\text { of hydrolysis, the greater the loss of viscosity with time } \\
\text { Viscosity reduced rapidly for the first } 10 \mathrm{~d} \text { followed by } \\
\text { slower and gradual decrease } \\
\text { All the specimens reached the same viscosity after } 60 \mathrm{~d} \\
\text { The presence of salt (sodium chloride) in the solution } \\
\text { reduced ageing }\end{array}$ \\
\hline Mächtle (1982) & $\begin{array}{l}\text { High-molecular-weight } \\
\text { (non-ionic) } \\
\text { polyacrylamide }\end{array}$ & $\square$ & $\begin{array}{l}\text { Details not given } \\
\text { Distilled water was used for mixing and } \\
\text { the solutions were stored in a sterile } \\
\text { environment at } 25^{\circ} \mathrm{C}\end{array}$ & Capillary viscometer & घ & Negligible change of viscosity over $62 d$ \\
\hline $\begin{array}{l}\text { Henderson and } \\
\text { Wheatley (1987) }\end{array}$ & $\begin{array}{l}\text { Anionic polyacrylamide } \\
\text { from } \\
\text { Allied Colloids with } 30 \% \\
\text { degree of hydrolysis }\end{array}$ & $\begin{array}{l}\square \\
\mathbf{\square} \\
\mathbf{\square} \\
\mathbf{\square}\end{array}$ & $\begin{array}{l}\text { Distilled water and coal preparation } \\
\text { plant water were used for mixing } \\
\text { After polymer addition, shaking for } 30 \mathrm{~s} \\
\text { and allowing the solution to stand for } 1 \mathrm{~h} \\
\text { Sodium nitrate }\left(\mathrm{NaNO}_{3}\right) \text { at a concentration } \\
\text { of } 1 \mathrm{M} \text { was added before viscosity } \\
\text { measurement } \\
\text { Solutions were stored in a glass container } \\
\text { in the daylight during ageing }\end{array}$ & Capillary viscometer & घ & $\begin{array}{l}\text { Little difference in the initial viscosity between the } \\
\text { distilled water and coal water specimens } \\
\text { The viscosity of both specimens reduced by } 11 \% \text { over } \\
88 \mathrm{~d} \\
\text { The addition of 3\% alcohol prevented viscosity loss }\end{array}$ \\
\hline $\begin{array}{l}\text { Likos et al. } \\
\quad(2004)\end{array}$ & $\begin{array}{l}\text { Granular and emulsion } \\
\text { polyacrylamides from two } \\
\text { different suppliers: } \\
\text { Baroid and PDSCo }\end{array}$ & - & $\begin{array}{l}\text { Stirring of fluid with a large metal spoon } \\
\text { for } 5 \mathrm{~min}\end{array}$ & Marsh funnel & घ & Viscosity increased by $24-92 \%$ after $48 \mathrm{~h}$ from mixing \\
\hline
\end{tabular}




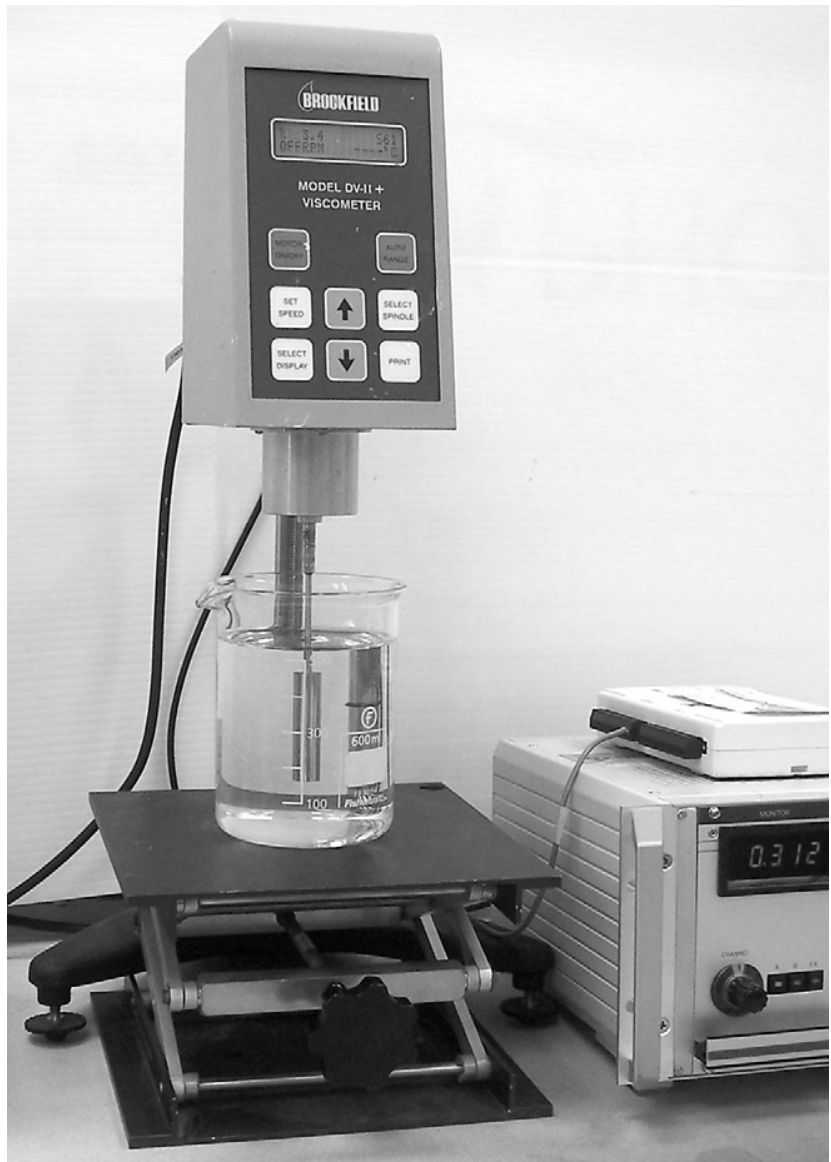

Figure 1. The Brookfield viscometer

In addition to the viscometer tests, ageing behaviour was monitored with a Marsh funnel as shown in Figure 2. This is a very simple device and is widely used for the on-site assessment of the relative viscosity of drilling and excavation fluids (e.g. FPS, 2006; Lam and Jefferis, 2015b). The test procedure is to fill the funnel with 1.5 litres of test fluid and record the efflux time for $946 \mathrm{ml}$ (one US quart) from the spigot. The time in seconds is recorded as the Marsh funnel viscosity (MFV). The MFV for water at $20^{\circ} \mathrm{C}$ is $26 \pm 0.5 \mathrm{~s}$. It is a manual test and cannot be done continuously.

Measurements were made every day for the first $10 \mathrm{~d}$ and at longer intervals thereafter. When not required for testing, the test fluid was stored in a sealed container in the temperaturecontrolled room at $23^{\circ} \mathrm{C}$.

Table 2 summarises the details of the five ageing tests performed in this study. The purpose of the first four tests (tests 1-4) was to assess the effect of mix water quality and also the influence, if any, of the choice of viscometer shear rate (speed

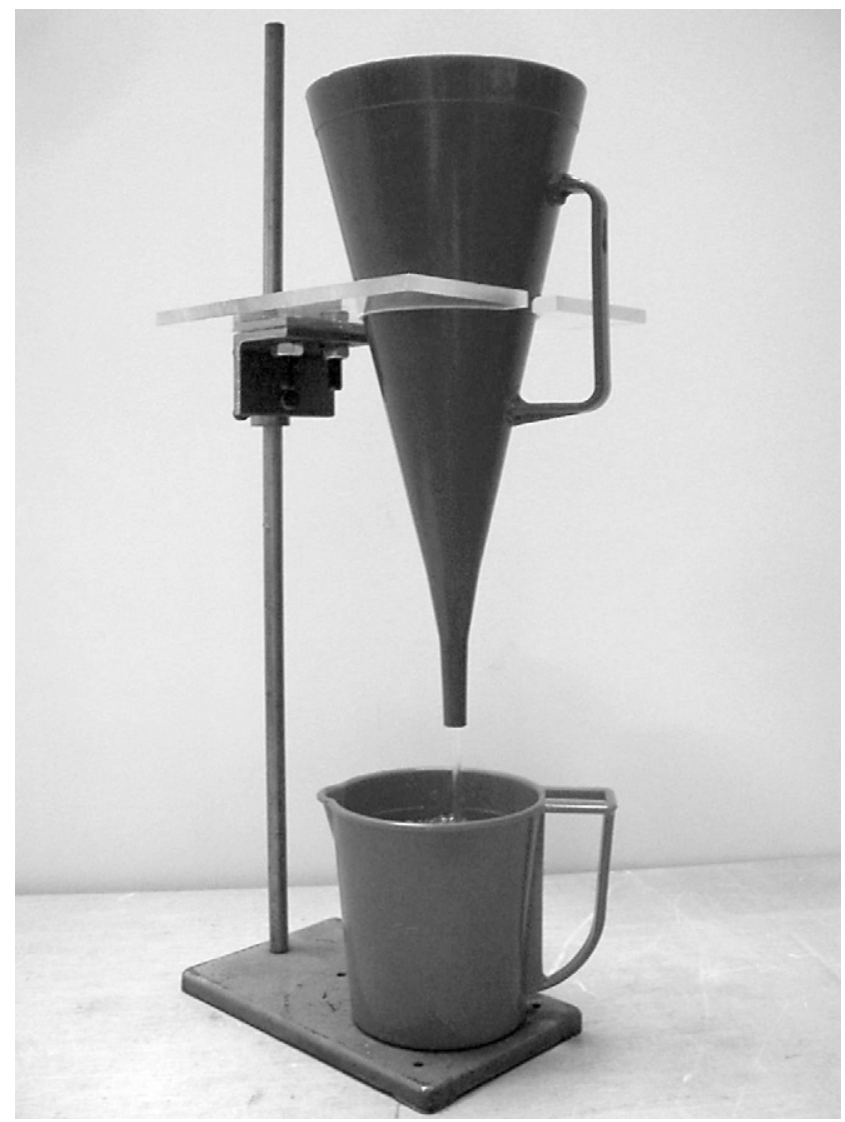

Figure 2. The Marsh funnel (reprinted from Lam and Jefferis (2015b), with permission, copyright ASTM International, 100 Barr Harbor Drive, West Conshohocken, PA 19428)

setting). Each of these tests lasted for between 23 and $33 \mathrm{~d}$. The slightly different test periods were due to the availability of the instrument in the authors' laboratory. On the basis of the previous test results of Henderson and Wheatley (1987), these times were considered sufficient for any important longer-term trends to be established, and certainly any trends likely to occur within the timescale of a typical fluid-supported excavation project. Furthermore, any initial rapid loss of viscosity, such as that observed by Kulicke and Kniewske (1981) and Shyluk and Stow (1969), was expected to develop over the first $5-10 \mathrm{~d}$ after mixing. Together, tests $1-4$ took about 4 months to complete. Test 5 , which was conducted using the Marsh funnel, was continued to $80 \mathrm{~d}$ to investigate the effects of longer-term storage.

\section{Results and discussion}

Figure 3 shows the results of tests 1 and 2 that were conducted on fluids prepared using deionised water but at different 


\begin{tabular}{lllll}
$\begin{array}{l}\text { Test } \\
\text { number }\end{array}$ & Mix water & $\begin{array}{l}\text { Viscosity measurement } \\
\text { procedure }^{a}\end{array}$ & Duration: d & Objective \\
\hline 1 & Deionised water & Brookfield viscometer, $3 \mathrm{r} / \mathrm{min}$ & 24 & To characterise the ageing behaviour of polymer \\
2 & & Brookfield viscometer, $20 \mathrm{r} / \mathrm{min}$ & 31 & fluids prepared using pure water \\
3 & Oxford tap water & Brookfield viscometer, $3 \mathrm{r} / \mathrm{min}$ & 23 & To characterise the ageing behaviour of polymer \\
4 & & Brookfield viscometer, $20 \mathrm{r} / \mathrm{min}$ & 33 & fluids prepared using hard water \\
5 & Deionised water & Marsh funnel & 80 & To assess the effect of viscosity measurement \\
& & & technique and long-term storage
\end{tabular}

In the Brookfield viscometer tests, the shear rates experienced by the fluid are 0.66 and $4.4 \mathrm{~s}^{-1}$ for the rotational speeds 3 and $20 \mathrm{r} / \mathrm{min}$, respectively (conversion factor equals 0.22 for spindle LV-1)

Table 2. List of ageing tests performed

viscometer measurement speeds ( 3 and $20 \mathrm{r} / \mathrm{min}$ corresponding to shear rates of 0.66 and $4.4 \mathrm{~s}^{-1}$ ). It can be seen that the apparent viscosity was very different at the two speeds. This is as expected since PHPA fluids are known to exhibit shear-thinning non-Newtonian behaviour, so that the lower the shear rate the higher the apparent viscosity (Lam and Jefferis, 2014b; Lam et al., 2015). In terms of their ageing characteristics, it can be seen that the viscosity of each of the specimens stayed near its initial value for the first 3-4 d and then followed a gradual reduction path until the end of the measurement period. At first sight, it would appear that the specimen in test 1 aged considerably more than that in test 2 due to the greater absolute reduction in viscosity. However, if the reduction is expressed in percentage terms, then both specimens showed comparable reductions $(18 \cdot 8$ and $15 \cdot 4 \%)$. This shows that no or very little extra degradation was caused by the higher shear stress applied to the sample tested at the higher spindle speed.

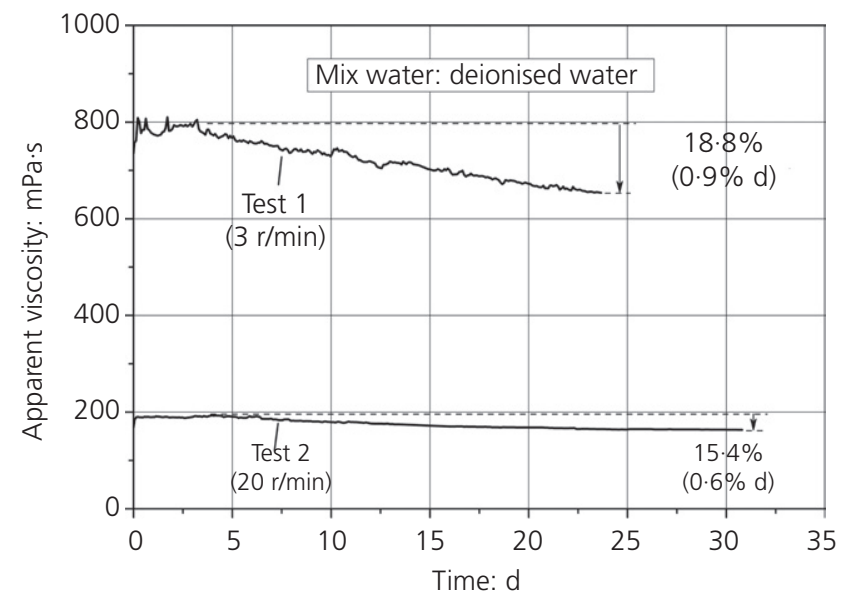

Figure 3. Viscosity-time profiles for PHPA polymer fluids prepared using deionised water
Had there been shear degradation, one would have expected a greater reduction in viscosity at the higher speed whereas the reverse was observed. The main conclusion that can be drawn from these results is that the PHPA fluid, at least under the test conditions described herein, did not display an initial rapid reduction in viscosity as described by some previous researchers (Kulicke and Kniewske, 1981; Shyluk and Stow, 1969). Rather, the viscosity-time profiles shown by tests 1 and 2 are more in line with those reported by Henderson and Wheatley (1987) and to a lesser extent those by Gardner et al. (1978). The cause of the gradual reduction in viscosity is possibly a conformational change of the polymer molecules leading to chain disentanglement as suggested by Narkis and Rebhun (1966).

Figure 4 shows the results of tests 3 and 4 that were conducted on fluids prepared with the sodium carbonate-treated

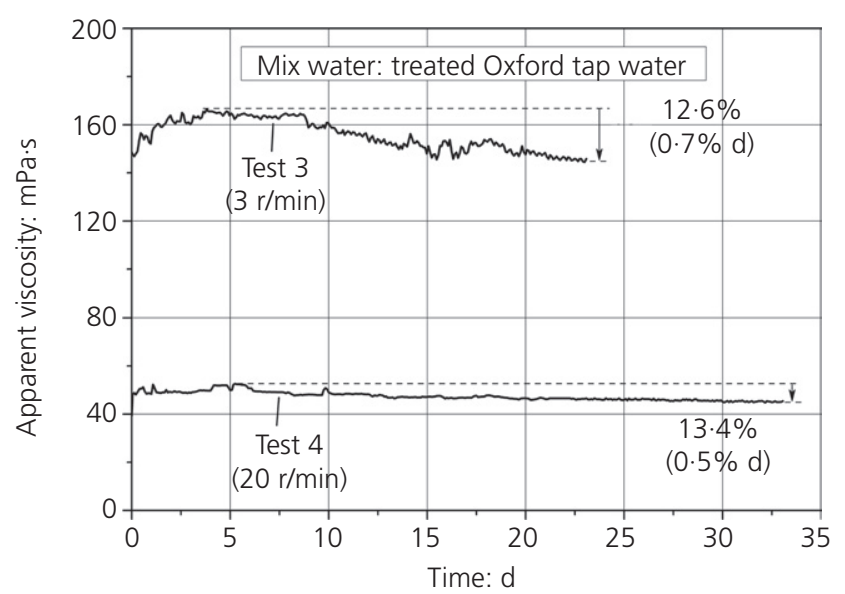

Figure 4. Viscosity-time profiles for PHPA polymer fluids prepared using sodium carbonate-treated Oxford tap water 
Oxford tap water. From comparison with Figure 3, it can be seen that the quality of mix water has a strong influence on the initial viscosity of the fluids, which dropped from around $800 \mathrm{mPas}$ in test 1 to $160 \mathrm{mPa}$ in test 3 (both tests at $3 \mathrm{r} / \mathrm{min}$ ) and from around $200 \mathrm{mPas}$ in test 2 to $50 \mathrm{mPa} \mathrm{s}$ in test 4 (both tests at $20 \mathrm{r} / \mathrm{min}$ ). Although it is known that the presence of dissolved ions can adversely affect the viscosity of polymer fluids (Jefferis and Lam, 2013), the magnitude of reduction was greater than expected as the hard water had been treated with soda ash following the polymer supplier's recommendation. As regards the ageing characteristics, it can be seen that the specimens again displayed a gradual reduction after a few days. The rates of reduction, expressed in per cent per day, are slightly lower than those seen in tests 1 and 2. This matches the finding of Kulicke and Kniewske (1981) that polymer fluids mixed with pure water age more than those mixed with salt water, although the samples prepared with salt water did show markedly lower initial viscosities.

Figure 5 shows the results of the Marsh funnel tests (test 5) that were conducted over an extended period of $80 \mathrm{~d}$. It can be seen that the ageing behaviour over the first $60 \mathrm{~d}$ is similar to that seen in the previous tests, although the rate of reduction is slightly lower at $0 \cdot 5 \% / \mathrm{d}$. However, given that the MFV for water is around $26 \mathrm{~s}$ and that MFV is, strictly speaking, a time measurement not a viscosity measurement, the results from this test are not strictly comparable with those discussed above. Nonetheless, it is interesting to see that the MFV stabilised after $60 \mathrm{~d}$, possibly due to the polymer molecules reaching an equilibrium condition. About $75 \%$ of the original viscosity remained at the end of the test.

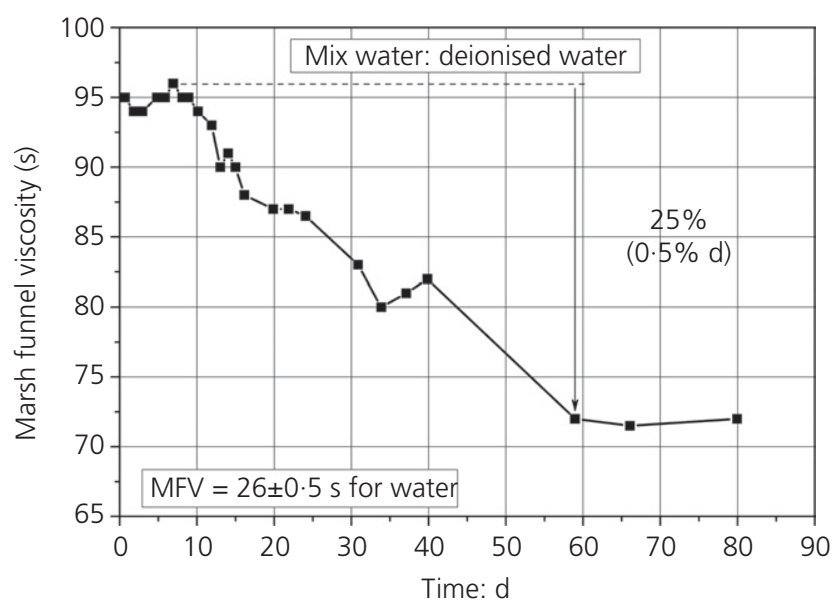

Figure 5. MFV-time profile for a PHPA polymer fluid prepared using deionised water

\section{Conclusions}

A series of ageing tests have been conducted on solutions of a high-molecular-weight PHPA. Both deionised and sodium carbonate-treated hard (Oxford tap) waters were used for fluid preparation. It was found that, contrary to the results of some of the previous studies, the viscosity of the fluids did not reduce rapidly within a few days from mixing. Rather, after a few days the fluids showed a gradual reduction in viscosity. This phenomenon is believed to be due to the conformational change of the polymer molecules, leading to a reduced amount of chain entanglement and so reduced viscosity. The rate of viscosity reduction appears to be slightly lower when treated tap water is used, although the tap water did markedly reduce the initial viscosity and so that this reduced rate of viscosity loss was from a lower baseline. An extended ageing test conducted using a Marsh funnel showed that the viscosity of the fluid reached a stable value at $60 \mathrm{~d}$ and then remained near constant to the end of the test at $80 \mathrm{~d}$. This was probably due to the polymer molecules reaching an equilibrium condition. It should be noted that the observed behaviour is based on a limited number of tests on a single PHPA product (Table 2) to an age of $80 \mathrm{~d}$. The ageing behaviour of other PHPA polymers may be somewhat different.

The practical relevance of this finding is that foundation contractors can expect the polymer fluid to retain a substantial proportion of its viscosity even after holding times up to a few months, times that may be unavoidable on large projects extending over long periods or as a result of plant breakdowns or if the fluid from one site is to be reused on another. In the future, it would be useful to repeat the tests on fluids that have been used in excavations but allowance would have to be made for sorption of the polymer onto soils.

\section{Acknowledgements}

The authors acknowledge the financial support of the Engineering and Physical Sciences Research Council (EPSRC) provided under grant references EP/C537815/1 and EP/ K503782/1. Balfour Beatty Ground Engineering Ltd and KB international LLC (USA) provided additional financial and technical support. The useful comments of the anonymous reviewers are much appreciated.

\section{REFERENCES}

Caulfield MJ, Qiao GG and Solomon DH (2002) Some aspects of the properties and degradation of polyacrylamides. Chemical Reviews 102(9): 3067-3083.

FPS (Federation of Piling Specialists) (2006) Bentonite Support Fluids in Civil Engineering, 2nd edn. Federation of Piling Specialists, Kent, UK.

Gardner KL, Murphy WR and Geehan TG (1978) Polyacrylamide solution ageing. Journal of Applied Polymer Science 22(3): 881-882. 
Henderson JM and Wheatley AD (1987) Factors effecting a loss of flocculation activity of polyacrylamide solutions: shear degradation, cation complexation, and solution ageing. Journal of Applied Polymer Science 33(2): 669-684.

Jefferis SA and Lam C (2012) Letter to the Editor: hydraulic characteristics of bentonite cake fabricated on cutoff walls. Clays and Clay Minerals 60(6): 557-560.

Jefferis SA and Lam C (2013) Polymer support fluids: use and misuse of innovative fluids in geotechnical works. In Proceedings of the 18th International Conference on Soil Mechanics and Geotechnical Engineering (Delage P, Desrues J, Frank R, Puech A and Schlosser F (eds)). Presses des Ponts, Paris, France, pp. 3219-3222.

Kulicke WM and Kniewske R (1981) Long-term change in conformation of macromolecules in solution, 2. Poly (acrylamide-co-sodium acrylate)s. Die Makromolekulare Chemie 182(8): 2277-2287.

Lam C and Jefferis SA (2014a) The use of polymer solutions for deep excavations: lessons from far eastern experience. HKIE Transactions 21(4): 262-271.

Lam C and Jefferis SA (2014b) Interpretation of viscometer test results for polymer support fluids. In Proceedings of Sessions of the Geo-Shanghai 2014 International Conference, Shanghai (Ding W and Li X (eds)). American Society of Civil Engineers, Reston, VA, USA, pp. 439-449, Geotechnical Special Publication No. 242.

Lam C and Jefferis SA (2015a) Performance of bored piles constructed using polymer fluids: lessons from European experience. Journal of Performance of Constructed Facilities, http://ascelibrary.org/doi/abs/10.1061/(ASCE)CF. 1943-5509.0000756.

Lam C and Jefferis SA (2015b) Physical properties of polymer support fluids in use and their measurement techniques. Geotechnical Testing Journal 38(4): 1-12.

Lam C, Jefferis SA and Goodhue KG Jr. (2010) Observations on viscosity reduction of PHPA polymer support fluids. In Proceedings of Sessions of the GeoShanghai 2010 International Conference, Shanghai (Liang RY, Zhang F and Yang K (eds)). American Society of Civil Engineers, Reston, VA, USA, pp. 184-191, Geotechnical Special Publication No. 205.

Lam C, Jefferis SA and Martin CM (2014a) Effects of polymer and bentonite support fluids on concrete-sand interface shear strength. Géotechnique 64(1): 28-39, http://dx.doi. org/10.1680/geot.13.P.012.

Lam C, Jefferis SA and Suckling TP (2014b) Construction techniques for bored piling in sand using polymer fluids. Proceedings of the Institution of Civil Engineers Geotechnical Engineering 167(6): 565-573, http://dx.doi. org/10.1680/geng.13.00128.

Lam C, Martin PJ, Jefferis SA and Goodhue KG Jr. (2014c)

Determination of residual concentration of active polymer in a polymeric support fluid. Geotechnical Testing Journal 37(1): 46-59.

Lam C, Martin PJ and Jefferis SA (2015) Rheological properties of PHPA polymer support fluids. Journal of Materials in Civil Engineering, http://ascelibrary.org/doi/abs/10.1061/ (ASCE)MT.1943-5533.0001252.

Lennon DJ, Ritchie D, Parry GO and Suckling TP (2006) Piling projects constructed with vinyl polymer support fluid in Glasgow, Scotland. In Proceedings of the 10th International Conference on Piling and Deep Foundations, Amsterdam (Lindenberg J, Bottiau M and van Tol AF (eds)). Deep Foundations Institute, Hawthorne, NJ, USA, pp. 499-506. Likos WJ, Loehr JE and Akunuri K (2004) Engineering Evaluation of Polymer-based Drilling Fluids for Applications in Missouri Shale. Department of Civil and Environmental Engineering, University of Missouri, Columbia, SC, USA, Report RDT-04-019.

Mächtle W (1982) Zur alterung von wäßrigen polyacrylamid-lösungen. Die Makromolekulare Chemie 183(10): 2515-2525 (in German).

Nakano A and Minoura Y (1978) Degradation of aqueous poly(acrylic acid) and its sodium salt solutions by highspeed stirring. Journal of Polymer Science 22(8): 2207-2215.

Narkis N and Rebhun M (1966) Ageing effects in measurements of polyacrylamide solution viscosities. Polymer 7(10): 507-512.

Schünmann D (2004) Fisherman's friend. Ground Engineering 37(12): 17.

Shyluk WP and Stow FS Jr. (1969) Ageing and loss of flocculation activity of aqueous polyacrylamide solutions. Journal of Applied Polymer Science 13(5): 1023-1036.

Suckling TP, Lam C, Jefferis SA and Pantling CJ (2011) Evaluation of causes of bleeding of free water from a bentonite slurry. In Proceedings of the 36th Annual Conference on Deep Foundations, Boston. Deep Foundations Institute, Hawthorne, NJ, USA, pp. 401-407.

\section{HOW CAN YOU CONTRIBUTE?}

To discuss this paper, please email up to 500 words to the editor at journals@ice.org.uk. Your contribution will be forwarded to the author(s) for a reply and, if considered appropriate by the editorial board, it will be published as discussion in a future issue of the journal.

Proceedings journals rely entirely on contributions from the civil engineering profession (and allied disciplines). Information about how to submit your paper online is available at www.icevirtuallibrary.com/page/authors, where you will also find detailed author guidelines. 